\title{
TRADE CONTROVERSY AMIDST TOBACCO CONTROL PROVISIONS: DYNAMICS ON THE ESTABLISHMENT OF U.S TOBACCO CONTROL ACT 2009
}

\author{
Puguh Toko Arisanto \\ Program Studi Ilmu Hubungan Internasional \\ Universitas Teknologi Yogyakarta \\ Puguh.arisato@staff.uty.ac.id
}

\begin{abstract}
This article examines the dynamics on the establishment of a health policy that U.S suddenly issued, socalled Family Smoking Prevention and Tobacco Control Act (FSPTCA). Some provisions of this act having something to do with trade were assumed controversial policy due to two reasons. First, it banned the circulations of specific flavors in cigarettes but allowed menthol-containing tobacco products. Second, this act involved tobacco industry participation on Tobacco Products Scientific Advisory Committee (TPSAC). In short, this article addresses interest groups consisting of tobacco companies and civil society groups influencing U.S government to take action regarding ratification of World Health Organization Framework Convention on Tobacco Control (WHO FCTC). They both have contradicting interests and race against each other to influence government through varied means. I argue that this opposing domestic dynamics influences U.S government to issue FSPTCA that contained two controversies and adopted provisions of WHO FCTC as win-win solution.
\end{abstract}

Keywords: tobacco control; interest groups; ratification; influence; win-win solution.

\begin{abstract}
Abstrak
Artikel ini membahas mengenai dinamika pembentukan sebuah kebijakan atau undang-undang kesehatan Amerika, FSPTCA yang dikeluarkan secara mendadak. Beberapa ketentuan dari undang-undang ini berkaitan dengan perdagangan dan diasumsikan sebagai kebijakan yang kontroversial karena dua alasan. Pertama, undang-undang ini melarang peredaran rokok beraroma rasa namun mengizinkan produk tembakau yang mengandung mentol. Kedua, undang-undang ini melibatkan partisipasi industri tembakau dalam sebuah kelompok para penasehat ilmiah produk tembakau. Singkatnya, artikel ini merujuk pada kelompok kepentingan yaitu perusahaan-perusahaan rokok dan kelompok masyarakat sipil yang mempengaruhi pemerintah dalam meratifikasi konvensi kerangka kontrol tembakau dari WHO. Mereka memiliki kepentingan yang saling bertentangan dan saling berlomba untuk mempengaruhi pemerintah Amerika melalui berbagai macam cara. Akhirnya, penulis beragumen bahwa dinamika domestik yang saling bertentangan mempengaruhi pemerintah AS untuk mengeluarkan kebijakan FSPTCA yang memuat dua kontroversi dan mengadopsi ketentuan WHO FCTC dengan dua kontroversinya sebagai win-win solution.
\end{abstract}

Kata Kunci: kontrol tembakau; kelompok kepentingan; ratifikasi; mempengaruhi; win-win solution.

\section{Introduction}

\section{Family Smoking Prevention and Tobacco Control Act}

Some decades, according to health experts, U.S slowly but surely had reduced the percentage of smokers through some tobacco control acts since 1960s. However, tobaccorelated diseases compared with the other diseases, still became the biggest and the most preventable cause of some diseases and premature deaths before 2010. ${ }^{1} 45$ million

\footnotetext{
${ }^{1}$ Smoking-Attributable Mortality, Years of Potential Life Lost, and Productivity Losses, United
}

adults were still active smoker and one fifth of U.S students were smokers. The big number of smokers tried to smoke and became addicted before their eighteenth. Kids tried the first cigarette every hour. ${ }^{2}$

States, 2000--2004,' Centers for Disease Control and Prevention, November 2008,

http://www.cdc.gov/mmwr/preview/mmwrhtml/mm 5745a3.htm, Accessed 10 August 2016.

2 '2009-2010: Inaugural Year in Review,' Food and Drug Administration Center for Tobacco Products, 2010, p.3,

http://www.fda.gov/downloads/TobaccoProducts/N ewsEvents/UCM216374.pdf, Accessed 25 August 2016. 
172 Puguh Toko Arisanto Trade Controversy Amidst Tobacco Control Provisions: Dynamics On The Establishment Of U.S Tobacco Control Act 2009

After passing governmental process, on June 2009 U.S government through Obama's signature officially issued a comprehensive tobacco control act to reduce and protect young generation namely Family Smoking Prevention and Tobacco Control Act (FSPTCA). This act gave Food and Drug Administration (FDA) authority to regulate the manufacture, distribution, and marketing of tobacco products to protect public health strictly in detailed provisions. ${ }^{3}$ FDA could also regulate tobacco products like cigarettes, tobacco, roll-your-own-tobacco and smokeless tobacco. This acts, in fact resembled or adopted some provisions from World Health Organization, Framework Convention on Tobacco Control (WHO FCTC) such as price and tax measures to reduce the demand for tobacco, measures to reduce promotion to youth, regulation of contents, packaging, labeling, advertising, and protection against exposure to tobacco smoke. ${ }^{4}$

This act seemingly has no problematic sides in common due to its objectives for the sake of the improved public health. Yet this act includes at least two controversies. First, this act based on section 907 (a)(1)(A) does not enable markets of specific flavors in cigarettes both artificial and natural flavors such some cigarettes containing fruits, clove, vanilla, coffee etc. ${ }^{5}$ They were officially illegal to be traded in U.S domestic market after 2009. U.S government claimed that flavored cigarettes

\footnotetext{
3 'About the FSPTCA,' National Institute of Health, 2010, https://prevention.nih.gov/tobaccoregulatory-science-program/about-the-FSPTCA, Accessed 1 August 2016.

${ }^{4}$ J.E.M. Sherrick, Food, Drugs, and Cigarettes:

The Influence of Politics on FDA

Regulations, University of Georgia, Atlanta, 2012, p.49-57.

5 'Family Smoking Prevention and Tobacco Control and Federal Retirement Reform,'U.S Government Publishing Office, 2009, https://www.gpo.gov/fdsys/pkg/PLAW111publ31/pdf/PLAW-111publ31.pdf, Accessed 9 August 2016.
}

are the gateway for the young to be regular smokers. ${ }^{6}$

Instead, this act allows menthol containing cigarettes which are mostly (about 90\%) produced both advertised as menthol and nonmenthol by big domestic tobacco companies notably the Big Three; Phillip Morris, Reynolds and Lorrilard. Ironically, many predominant domestic health institutions clarified conclusively that all tobacco products both menthol or non-menthol are harmful and different treatments are really not necessary. ${ }^{7}$ This act consequently damaged Indonesian clove cigarette exports and caused milliondollar loss for Indonesian clove tobacco companies. Indonesia then won the trade dispute settlement against U.S in the Dispute Settlement Body (DSB).

Second, this act allows tobacco industry representatives to take part and all at once to be members of Tobacco Products Scientific Advisory Committee (TPSAC) in the decision making about the impact of the use of menthol in cigarettes on the public health. Of 12 members hired in TPSAC both as voting and non-voting members, industry representatives place 3 members as non-voting members. ${ }^{8}$ Despite non-voting members, these representatives can potentially have important roles in decision making process. The rest members must involve and put non-voting member's considerations as important sources. This tobacco industry involvement remains controversial regarding the track record of

\footnotetext{
6 'Candy and Fruit Flavored Cigarettes Now Illegal in United States; Step is First Under New Tobacco Law,' Food and Drug Administration, 2009, http://www.fda.gov/NewsEvents/Newsroom/PressA nnouncements/ucm183211.htm, Accessed 9 August 2016.

7 'Menthol Cigarettes,'Smokefree.gov, http://teen.smokefree.gov/Menthol-cigarettes.aspx, Accessed 10 August 2016.

8 'Tobacco Products Scientific Advisory Committee,' Food and Drug Administration, http://www.fda.gov/AdvisoryCommittees/Committ eesMeetingMaterials/TobaccoProductsScientificAd visoryCommittee/default.htm, Accessed 11 August 2016.
} 
173 Puguh Toko Arisanto Trade Controversy Amidst Tobacco Control Provisions: Dynamics On The Establishment Of U.S Tobacco Control Act 2009

most tobacco industries which ceaselessly seek to undermine tobacco control policies elsewhere. Even, this ten to one could be worse if tobacco industries take part in public health policy such tobacco control act. Tobacco Industry involvement is seriously not justified by WHO FCTC based on article 5.3. ${ }^{9}$ This article is put on much emphasized matter by WHO FCTC because tobacco industries are perceived powerful threats to the public health policies and tend to spoil, undermine or even subvert tobacco control acts in the rest of the world. Although U.S has yet to ratify WHO FCTC, tobacco involvement on tobacco control policy is highly questionable.

Given those two controversies, the author notes that the establishment of FSPTCA is not solely for health objectives, behind the scene political economy motives seem to take roles. J.E May Sherrick on her thesis "Food, Drugs, and Cigarettes": The Influence of Politics on FDA Regulations" stated that after released, FSPTCA resided controversial stories. FDA as the main actor undertaking FSPTCA took no response or a step forward regarding the findings of TPSAC that menthol containing tobacco products are harmful just like common cigarettes. This silent action strongly proved that menthol issue was purely a political issue. ${ }^{10}$ In a line with this, Michael Siegel on "TPSAC Menthol Report Answers the Scientific Questions, But Doesn't Tip Committee's Hand, Demonstrating this is About Policy and Politics, Not Science" wondered about FSPTCA. Excluding menthol containing tobacco products was not rooted from scientific findings. Political approach won against scientific approach. ${ }^{11}$ A different

\footnotetext{
9 'Guidelines for implementation of Article 5.3 of the WHO Framework Convention on Tobacco Control,' World Health Organization, http://www.who.int/fctc/guidelines/article_5_3.pdf, Accessed 13 August 2016.

${ }^{10}$ J.E.M. Sherrick, Food, Drugs, and Cigarettes:

The Influence of Politics on FDA

Regulations, p.49-57.

${ }^{11}$ Siegel, 'TPSAC Menthol Report Answers The

Scientific Questions, But Doesn't Tip Committee's
}

view was posed by Maya Meralda Kartika on "Proteksionisme Amerika Serikat Pasca Krisis Finansial 2008" stating that FSPTCA was one of U.S instruments to recover a severely financial crisis in 2008. FSPTCA aimed at protecting domestic products after the crisis. ${ }^{12}$ Filling the gap of the literatures, this article will focus on dynamics of domestic actors as interest groups which influences U.S government to issue FSPTCA.

\section{United States and Ratification of WHO FCTC}

Shortly after the draft of WHO FCTC were released, hundreds of countries in throngs followed Norway's steps to sign and ratify the treaty some years later. ${ }^{13}$ Strangely, U.S was the only powerful country postponing and languishing the future of the treaty ratification. U.S had signed it in 2004 but had not given a ratification signal some years later. The absence of U.S in the global health treaty was regrettably perceived as an irony by many stakeholders putting much on public health attention. Previously, many health experts followed by developing states and Health NGOs (both domestic and international) had deplored for U.S government's deed. Framework convention Alliance (FCA) as representative of international actors in international level had pushed many states to ratify WHO FCTC in a line with assistance on

Hand, Demonstrating This Is About Policy And Politics, Not Science,' Tobacco Analysis, 18 March 2011,

http://tobaccoanalysis.blogspot.co.id/2011/03/tpsacmenthol-report-answers-scientific.html, accessed 15 Agust 2016.

${ }^{12}$ M.Y. Kartika, 'Proteksionisme Amerika Serikat Pasca Krisis Finansial 2008,' Jurnal Analisis Hubungan Internasional UNAIR, vol.2 no.3, 2013, p. 10

13 'Updated Status of the WHO FCTC: Ratification and Accession by Country,' Framework Convention Alliance, 2009, p.9, http://www.fctc.org/publications/other-fcapublications/doc_view/131-updated-status-of-thewho-fctc-ratification-and-accession-by-country, Accessed 20 August 2016. 
174 Puguh Toko Arisanto Trade Controversy Amidst Tobacco Control Provisions: Dynamics On The Establishment Of U.S Tobacco Control Act 2009

development, ratification and implementation of the treaty. However, for U.S, FCA imposed a little pressure (even almost no). It was seemingly due to U.S power and dominance on global health issues. FCA afterwards preferred to subordinate this task to U.S domestic health NGOs seeing that many U.S health NGOs are prominent and expected to give strong pressure on ratification. ${ }^{14}$

The absence of U.S in global health treaty was highly questionable. First, U.S, powerful state, constituted the five biggest of smoker countries accounting for 45 million active smokers. ${ }^{15}$ Second, U.S inevitably had to recognize a fact that there exists one of the biggest tobacco companies in the world, Philip Morris. In so doing U.S constituted one of the biggest tobacco producers in the world. ${ }^{16}$ Philip Morris has a highly broad market in around 180 countries and operates in tens of countries so it means U.S had inevitably contributed to global diseases due to tobacco product of the tobacco company. Third, U.S was once one of leading countries in global health and became global trendsetter in tobacco control acts. In addition to this, U.S along with NGOs, health foundations, universities and commercial entities had long contributed to global health initiatives and provided source of global insights, big global funds such as Bloomber Initiatives, capacity building, and many more. ${ }^{17}$ Procrastinating or

\footnotetext{
${ }^{14}$ Online interview with Chris Bostic, Deputy Director for Policy of FCA, 10 August 2016.

15 'The Global Tobacco Crisis : Tobacco- Global Agent of Death,' World Health Organization, 2008, p.19,

http://www.who.int/tobacco/mpower/mpower_repor t_tobacco_crisis_2008.pdf?ua=1, Accessed 10 August 2016.

${ }^{16}$ David, 'A Review of the Global Tobacco Industry,' Topforeignstocks, 14 November 2010, http://topforeignstocks.com/2010/11/14/a-reviewof-the-global-tobacco-industry/, Accessed 2 September 2016.

17 'The U.S. Commitment to Global Health: Recommendations for the Public and Private Sectors,' The National Academies, 2009, p.1-2. http://sites.nationalacademies.org/cs/groups/internat
}

even objecting to ratification of the WHO FCTC, U.S was obviously in contrast to its huge contributions to global health.

\section{Domestic Dynamic of Two Opposing Parties: Tobacco Companies and Civil Society Groups.}

Interest groups in some decades had significant roles in the U.S political constellation. Since 1964, the roles of interest groups had changed drastically and ceaselessly took a part in all aspects of the policy-making process as well as on the election process. ${ }^{18}$ Although most interest groups are separated from institutions as political parties, some interest groups provide differing views and help link up between societies and governments and are capable of influencing the issued policies of the U.S government with the views they have and partly on behalf of the public interests. To influence the government, they employ some means such as lobbying the government, engaging in election activities, educating the public and mobilizing the community on certain issues. ${ }^{19}$

The main point of this passage is how two opposing parties, tobacco companies and civil society groups as interest groups, influence U.S government regarding between agreement on ratification or objection to ratification through the varying means. The given condition, different natures between tobacco companies and civil society groups in some contexts bring about different ways to do actions.

\section{The Influences of Tobacco Companies}

ionalsite/documents/webpage/international_053818 pdf, Accessed 2 September 2016.

${ }^{18}$ L.Miller,'Interest Groups,' Collin College, https://iws.collin.edu/lmiller/2305\%20Powerpoint/1 3\%20Interest\%20Groups.pptx, Accessed 20 September 2016.

19 'Interest Groups: Organizing To Influence,' Annenberg Learner, https://www.learner.org/courses/democracyinameri ca/dia_14/dia_14_topic.html, Accessed 22 September 2016. 
175 Puguh Toko Arisanto Trade Controversy Amidst Tobacco Control Provisions: Dynamics On The Establishment Of U.S Tobacco Control Act 2009

In the U.S history, tobacco industries have provided big economic advantages due to national income, profit, taxation and a number of huge job forces for the country. ${ }^{20}$ Tobacco companies in particular the Big Three have inevitably huge contributions to national economy. Through excise tax, from 2000 to 2008 tobacco companies provided 7,7 billion dollars per year for Federal Government. ${ }^{21}$ and 10,98 billion dollars per year for State and Local Government. ${ }^{22}$ Tobacco companies did not only enliven around more than twenty thousand workers and help tobacco farmers survive but they also foster the other sectors beyond tobacco on agriculture sectors. In instance, these encompass around six hundred thousand workers from upstream business to downstream business. ${ }^{23}$ Finally, the tobacco companies also help U.S economy reap foreign exchanges via tobacco export commodity accounting for more than one billion per year. ${ }^{24}$

In U.S tobacco product market, the Big Three have long dominated for almost $90 \%$ of U.S domestic market which Phillip Morris conquered around $50 \%$ compared to Reynolds and Lorillard with only $29 \%$ and $11 \%$ respectively. Of all tobacco products sold in U.S market, a large number (almost all) is

\footnotetext{
${ }^{20}$ J.Simms, 'The Political Economy of the Tobacco Industry,' Elon University, http://org.elon.edu/ipe/simms.pdf, Accessed 2 June 2016.

21 'Tobacco Tax Revenue and Forecast in the United States from 2000 to $2021^{*}$ (in billion U.S. dollars),' The Statistics Portal, 2016, https://www.statista.com/statistics/248964/revenues -from-tobacco-tax-and-forecast-in-the-us/, Accessed 7 September 2016.

${ }^{22}$ 'State and Local Tobacco Tax Revenue, Selected Years 1977-2013,' Tax Policy Center, 2016, http://www.taxpolicycenter.org/statistics/tobaccotax-revenue, Accessed 10 September 2016.

23 'Tobacco Industry,' Encyclopedia, November 2006 ,http://www.encyclopedia.com/history/unitedstates-and-canada/us-history/tobacco-industry, Accessed 12 September 2016.

24 'Top Export-Cigarettes 2003, 2004, 2005, 2006 \& 2007,' Food and Agricultural Organization, http://faostat.fao.org/site/342/default.aspx, Accessed 17 September 2016.
}

menthol-containing product. Yet, only $25-30 \%$ is promoted and advertised as menthol cigarettes. $^{25}$ While, the rest is non-menthol cigarettes even so in fact they also contain menthol with less amount.

Aside from the substantial economic contributions to the U.S economy, tobacco companies also prepared a promising political contribution for the rulers. Every year tobacco companies notably the Big Three provide millions of dollars to prospective officials in the federal government both at the executive and legislative levels (Congress) almost entirely dominated by Republican and Democratic parties. The high officials constitute Federal candidates in short consisting of the President, Vice President, Parliament and the U.S Senates. The flowing funds are taken advantage of an opportunity for the nomination campaign indicating that the candidates can issue a favorable policies or at least more friendly for the long-term sustainability of tobacco companies after successfully elected at the Federal Office.

Diagram 1. Contributions to Federal Candidates, Parties and Outside Groups from Tobacco Sector (US\$)

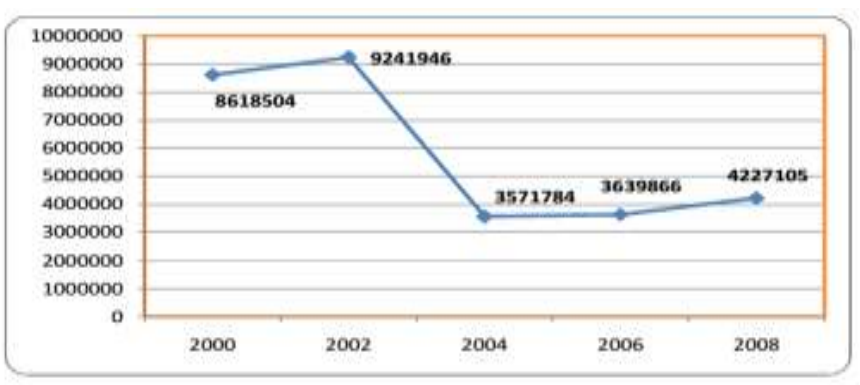

Source: Center for Responsive Politics ${ }^{26}$

The diagram above shows political contributions of tobacco companies to both federal and political party candidates

\footnotetext{
${ }^{25}$ Smokefree.gov, 'Menthol Cigarettes'.

26 'Tobacco: Long-Term Contribution Trends (2000, 2002, 2004, 2006, 2008),' Center for Responsive Politics,

https://www.opensecrets.org/industries/totals.php?c ycle $=2016 \&$ ind $=$ A02, Accessed 17 September 2016. Note : the real amount of the money is much larger than in the data.
} 
176 Puguh Toko Arisanto Trade Controversy Amidst Tobacco Control Provisions: Dynamics On The Establishment Of U.S Tobacco Control Act 2009

(Republican and Democratic) spending millions of dollars per year. Despite its drastic decline in 2004 due to McCain-Feingold Law strictly banning the existence of bribes or gratuities from individuals and companies to the people of the national political parties for campaign activities, the flow of funds kept flowing although the act had come into force. Of the contributions, the Big Three still had a large contribution amount compared to other tobacco companies or cigarette companies. ${ }^{27}$

It is the same with federal office, tobacco companies with many intentions pour millions of dollars annually into members of the U.S incumbent Congress members mostly inhabited by the Senates and House of Representatives of the Republican and Democratic parties.

27 'Tobacco: Top Contributors to Federal Candidates, Parties, and Outside Groups (2000, 2002, 2004, 2006, 2008),' Center for Responsive Politics, https://www.opensecrets.org/industries/contrib.php? ind $=$ A02 $\&$ Bkdn $=$ DemRep $\&$ cycle $=2004$, Accessed 17 September 2016. 
177 Puguh Toko Arisanto Trade Controversy Amidst Tobacco Control Provisions: Dynamics On The Establishment Of U.S Tobacco Control Act 2009

Chart 1. Money to Congress (Incumbent House and Senate) From

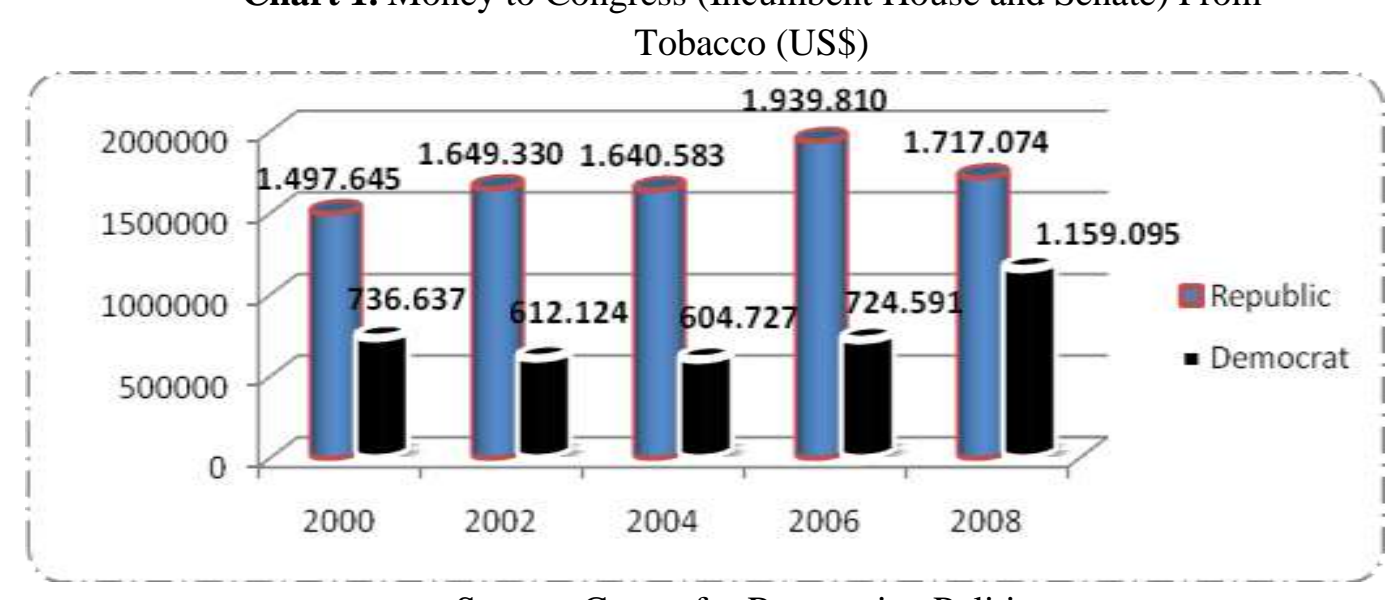

Source: Center for Responsive Politics

The flowing funds (see chart 1$)^{28}$ to the Congress members confirm the importance of money in the record of the U.S administration. This was once disclosed by Edward Kennedy, one of the U.S Senators who said "Money is the mother's milk of U.S politics, we have the best Congress money can buy and you have to pay to play". ${ }^{29}$ Funds of political aspiration flowing denote that Congress will often take in favor of the contributor's interests, tobacco companies.

The aforementioned explanations brought into an idea about money politics as a national public secret. In the history of tobacco politics, tobacco companies possessed a quite big power to influence tobacco control policies. For example, in the 1990s U.S tobacco companies committed as many called "the end justifies the means" in terms of reducing the provision of public health policy. A study showed that tobacco companies put aggressive and comprehensive political efforts related to state legislation in order to sell

\footnotetext{
28 'Tobacco, Money to Congress (Incumbent Only) 2000, 2002, 2004, 2006, \& 2008,' Center for

Responsive Politics,

https://www.opensecrets.org/industries/summary.ph p?cycle $=2004 \&$ ind $=$ A02, Accessed 16 September

2016. Note : the real amount of the money is much larger than in the data.

${ }^{29}$ M.Simpson, 'US Politics: Pressure Groups,

Newtown and the NRA,' Tutor $2 u$,

http://www.tutor2u.net/politics/blog/revisionupdate-us-politics-pressure-groups-newtown-andthe-nra, Accessed 2 September 2016.
}

tobacco with the smallest barriers. They intensively employed varying means through lobbying, mass media, public relations, illegal groups, industry alliances and donations to lawmakers. These efforts included campaigns to neutralize clean indoor air legislation, minimized tax increases, and protected the industry's freedom to advertise and sell tobacco products. ${ }^{30}$ As a result, many states have finally not enforced stricter tobacco control laws. This exposure concluded that tobacco companies could afford to become powerful actors in the face of state health policies and tobacco companies were able to use them secretly behind the scenes.

In the early 2000s, the polemical issue was the WHO FCTC signed by the U.S government gave a dawn warning for domestic tobacco companies. U.S tobacco companies would be potentially threatened by the ratification and implementation of the $\mathrm{WHO}$ FCTC which would bring comprehensive tobacco control policies ranging from progressively cigarette tax adjustment, cigarette packaging and labeling, cigarette production and distribution, advertising and sponsorship rules on cigarettes to prohibition of selling cigarettes on minors and so forth. It has been a popular public secret and there have

\footnotetext{
${ }^{30}$ M.S. Givel \& S.A. Glantz. 'Tobacco Lobby Political Influence on US State Legislatures in the 1990s,' British Medical Journal, vol.10, Issue 2, no.124, 2001. p.3.
} 
been arguments from some research that tobacco companies anywhere were clearly in a position to oppose such international treaty to be ratified and implemented by any government ${ }^{31}$ without an exception to U.S government.

Philip Morris told in a conference that regardless of WHO FCTC ratification, the treaty would have a significant impact on Philip Morris as it would accelerate tobacco control measures in each country. ${ }^{32}$ This context clearly led by hand to negative impacts and came to be a threat to the sustainability of Philip Morris operations in various countries including in U.S market. In this position, policy makers at the executive and the legislative levels of U.S government would most likely consider the contributions of tobacco companies in economy and politics, especially the Big Three, worth millions and even billions of dollars highly important input to issue a policy that favors tobacco companies' interests. In a different view, tobacco contribution to national economy and money politics flowing would become strong pressure to government not to ratify and implement WHO FCTC.

\section{Domestic Civil Society Groups' Pressure on U.S Ratification}

In the early 2000s, one of the health issues taking much attention for certain interest groups was WHO FCTC. The treaty continuously grabbed huge concern from various types of domestic interest groups such as academics, philanthropic organizations (NGOs), research institutions, and civil

\footnotetext{
${ }^{31}$ S. Glantz, H.M. Mamudu, \& R.Hammond, 'Tobacco Industry attempts to counter the World Bank Report Curbing the Epidemic and Obstruct the WHO Framework Convention on Tobacco Control,' National Center for Biotechnology Information, 2008, https://www.ncbi.nlm.nih.gov/pmc/articles/PMC26 62513/, Accessed 17 September 2016.

${ }^{32}$ J.Collin, 'Tobacco Politics,' Palgrave

Development, vol.47, issue 2, 2004, p. 96.
}

society $^{33}$ (apart from tobacco industries and their alliances as interest groups).

In the course of legal actions, the response to WHO FCTC became much more prominent when U.S government seemed to ponder amidst ratification or objection. Year after year, until 2008 U.S government still was silent and did not take legal actions about the treaty. U.S government took an opposite step while hundreds of countries had gradually ratified the treaty not until 4 years after the first ratification. The U.S inaction sparked controversy and delivered various questions.

U.S legal actions that had not ratified the WHO FCTC had received various pressures for some years from various civil society groups raising concern with public health issues. They consistently urged U.S government from Bush administration to the beginning of Obama administration to ratify and implement WHO FCTC. The pressures were by and large carried out with various means of emailing, faxing, calling or visiting members of the House of Representatives and Senates who support health public to influence and encourage U.S government (executive level) to ratify WHO FCTC. Moreover, they were also actively writing in mass media, such as local and national newspapers to keep the issue alive and induce the people to call for national ratification. Last, they mobilized the society as well to sign an online petition for national ratification to U.S government. ${ }^{34}$

\footnotetext{
33 'Interest Groups: Organizing To Influence,' Annenberg Learner,

https://www.learner.org/courses/democracyinameri ca/dia_14/dia_14_topic.html, Accessed 22 September 2016 .

${ }^{34}$ Nichter et al, M. 'The WHO Framework Convention on Tobacco Control, An Urgent Call for U.S. Ratification - Alcohol, Drug, and Tobacco Study Group (ADTSG),' Medical Anthopology Quarterly, 2007, http://www.medanthro.net/policy/priorstatements/tobacco-control/, Accessed 2 September 2016.
} 
There were a number of civil society groups urging ratification of WHO FCTC as follows: $:^{35}$

American Cancer Society (ACS) urged the U.S government to ratify WHO FCTC by publishing an ad in the Washington Post on 12 July 2006 asking for public advocacy in support of WHO FCTC. The ad persuaded and asked all U.S citizens to call in on President Bush to send WHO FCTC to the Senate for ratification $^{36}$. In addition, then ASC also made online petition through: <Http://lungaction.org/campaign/RatifyFCTC> - The petition was an electronic letter addressed to the President and Senate members voicing to ratify the global health treaty. ${ }^{37}$

American Medical Association (AMA) in $2003 \& 2004$ had several times sent letters to the Secretary of the Ministry of Health and Human Services as well as U.S representative at WHO FCTC, Thompson on AMA support for the FCTC by providing assistance and securing ratification by the U. S government. The AMA had also sent a letter urging President Bush to immediately bring the draft of WHO FCTC to the Senate for ratification. Aside from President, AMA had also sent letters, met and discussed actively with Senators about ratification. ${ }^{38}$

In 2004 \& 2005, Campaign for

Tobacco-Free Kids stated clearly for its urging view for U.S government to follow

\footnotetext{
${ }^{35}$ The data may only encompass a few of many actions the NGOs and Institutions had done 36 'American Cancer Society Cancer Action Network Launches Push for Ratification of Landmark Global Public Health Treaty,' American Cancer Society, 12 July 2006, http://www.acscan.org/mediacenter/view/id/61/, Accessed 20 September 2016.

${ }^{37}$ 'How to get Involved,' Rx for Change UCSF, http://documentslide.com/documents/how-to-getinvolved.html, Accessed 2 September 2016.

38 'Follow-Up Implementation of Resolutions and Report Recommendations : AMA House of Delegates Annual Meeting - June 14-19, 2003,' American Medical Association, 2003, http://www.amaassn.org/meetings/public/interim05/i04status.doc, Accessed 21 September 2016.
}

many countries footsteps ratifying and supporting implementation of WHO FCTC both domestically and internationally. It had also requested Bush to immediately submit WHO FCTC's draft to the Senate and asked Senate to ratify it. It stated that U.S inevitably had leadership responsibility in reducing tobacco use globally due to home of one of the biggest tobacco companies in the world. If China, Japan, and India as some huge tobacco producing countries could manage to cope with domestic tobacco industry's influence, U.S should have done as well. ${ }^{39}$

Society for Medical Anthropology (SMA), based on a released article in 2007, had many times urged U.S government to ratify WHO FCTC through various means. SMA claimed to have sent an email and fax, gone to President and Senators and written on various newspapers to keep the discourse of the ratification still alive to the public. ${ }^{40}$

The other civil society groups pushing for ratification were Corporate Accountability International, AAFP (American Academy of Family Physicians), AACR (American Association for Cancer Research), American Heart Society (AHS), Faith United Against Tobacco, American Lung Society (ALS), Action on Smoking and health (ASH), Essential Action, American Society of Clinical Oncology (ASCO), etc.

Responding to the massive pressures from various civil society groups, Bush administration in general did not take of the pressure very seriously. They did not hand the text over to Senate for ratification. When many asked to Bush administration, the spokesman easily gave a rhetorical answer that they

\footnotetext{
39 'China, World's Largest Cigarette Market, Ratifies Tobacco Treaty; U.S. Still On the Sidelines Because of Failure to Ratify', Campaign for Tobacco-Free Kids, 29 August 2005, http://www.tobaccofreekids.org/press_releases/post/ id_0866, Accessed 20 September 2016.

${ }^{40}$ M. Nichter et al, 'The WHO Framework Convention on Tobacco Control, An Urgent Call for U.S. Ratification - Alcohol, Drug, and Tobacco Study Group (ADTSG)'.
} 
actually supported the ratification of the WHO FCTC but the text was still drifting about or under review process in the State Department. ${ }^{41}$ Meanwhile at the beginning of Obama presidency, this pressure was still alive but Obama administration did not clearly take significant progress for ratification. ${ }^{42}$ Civil society groups eventually, given that Obama's commitment during his campaign for Presidency about his ratification of WHO FCTC and his track record as Senate member pushing for ratification of WHO FCTC, put high expectation for Obama administration to undertake the ratification. They believed Obama administration's treatment about WHO FCTC was much better than Bush Administration.

The insistence of various civil society groups denoted strong public interest for U.S government so as to ratify and enact WHO FCTC. Strong pressure from various groups as a process of interest articulation could not be solely ignored by U.S government during the Obama administration. Such pressure would be an important consideration point to determine what policy U.S government would take on ratifying or issuing different alternatives of policy.

\section{Discussion}

Robert Putnam stated about theory of ratification on two-level game approach that leaders (heads of government representing countries, ministers, leaders of the House of Representatives and Senate conference committees as well as leaders of ethnic groups) have no independent policy preferences but rather how to derive endorsement from their constituents. Ratification takes place in

\footnotetext{
${ }^{41}$ B.A. Liang, J.P., Pierce, L. Huber \& C. Bostic, 'Call to Action: Promoting Domestic and Global Tobacco Control by Ratifying the Framework Convention on Tobacco Control in the United States,'Plos Medicine, vol.11, issue.5, 2014, p.1. ${ }^{42}$ N. Nedzhvetskaya \& J.A. Powell, 'Who Do you Support,' The harvard Crimson, 2011, http://www.thecrimson.com/article/2011/4/11/tobac co-use-states-you/, Accessed 20 September 2016.
}

domestic level where leaders hold separate discussions with each constituent group and the results will put into effect the bargaining of international negotiators in international level. Although ratification is formally executed at the Senate level via voting, the important actors in the ratification as bureaucratic agencies, interest groups, social class as well as public opinion to some extent take roles. ${ }^{43} \mathrm{I}$ argue that interest groups become the stressed point and all at once have significant roles in influencing U.S government decision whether agreement on ratification or rejection to ratification. Interest groups at domestic level need exploring rather than actors at international level with little or even no impact on the decision. This stand point deals with domestic dynamics between tobacco industries and civil society groups which are in need of win sets rather than considerations between international level and domestic level.

The process of ratification initially commenced at domestic dynamics addressing on tobacco influence and civil society group's demands. Their interests were highly different even contradicting each other. First, Tobacco companies in particular the Big Three enjoy the power to influence U.S government due to, in short, their large contributions to national politics and economy. These large contributions inexorably embody close relationship between U.S government and domestic tobacco companies. Thus, U.S government under Obama administration needed to consider the contributions both economically and politically to make the best policy forward. In clear context, the contributions of tobacco companies could be domestic pressure for U.S government not to ratify WHO FCTC because the ratification may mostly be considered as threat to operations and existences of tobacco companies.

\footnotetext{
${ }^{43}$ R.D. Putnam, 'Diplomacy and Domestic Politics: The Logic of Two-Level Game,' International Organization MIT, vol. 42, Issue. 3, 1988, p.436.
} 
181 Puguh Toko Arisanto Trade Controversy Amidst Tobacco Control Provisions: Dynamics On The Establishment Of U.S Tobacco Control Act 2009

Aside from tobacco companies, at different foot U.S government was also dealing with domestic civil society groups in the health sector urging for ratification. The ratification of WHO FCTC means U.S domestic and international protection of health matters all at once in a good line with hundreds of countries which have ratified it. The insistence of civil society groups upon U.S government was not significantly heeded by Bush administration marking close ties between government and tobacco industry. The administration played rhetoric about their support to ratification but the text of the agreement was claimed still under review in the state department. Nevertheless, the insistence emanating from massive civil society groups through various means certainly provided a precedent of important consideration for the Obama administration to put the best policy forward. During his office as Senator, Obama was one supporting the ratification of WHO FCTC.

The mini illustration poses "If U.S government meet the insistence of civil society groups and some health facts by ratifying WHO FCTC then what about the interests of tobacco companies threatened by the tobacco control policy?" On the other hand, "If U.S government complies with the influence and interests of tobacco companies by not ratifying WHO FCTC, then what about the insistence of the civil society groups and some health facts?"

Without option but facing two different pressures, U.S government is supposed to win both games for the sake of safe, rational achievements for two opposing parties. Thus, U.S government inevitably sought to meet their contradicting interests as win-win solution. In other words, U.S government issued for how to make decisions that can meet these pressures. Lately, I thought, this was muddled by U.S government by issuing FSPTCA in 2009. FSPTCA in another context is a win-win solution for satisfying those two opposing parties. FSPTCA passing at the Congress level then was signed by President Obama resulting in a tobacco control act that accommodated tobacco industries and civil society group's interests.

FSPTCA issued in 2009 also constitutes that U.S government has made up its mind instead of ratifying WHO FCTC. U.S government was in favor of setting up an own tobacco control act adopting some important provisions of WHO FCTC. That U.S government had signed WHO FCTC was solely tentative agreement in need of domestic level process of endorsement.

The tobacco control act seeks to meet pressures emanating from civil society groups but on the other hand economically considers the viability of domestic cigarette companies all at once as reflected by the two controversies in FSPTCA provisions. Two controversies consisting of the exception of menthol cigarette ban in U.S domestic market and the involvement of tobacco companies in decisionmaking under FSPTCA through TPSAC are concessions granted by U.S government as a result of the implementation of FSPTCA. These concessions are in other words considered provisions that defend the interests of U.S tobacco companies amidst the implementation of FSPTCA. The reason why U.S excluded the ban on menthol cigarettes in FSPTCA because $90 \%$ of cigarettes produced by U.S domestic tobacco companies contain menthol although only $30 \%$ of cigarettes containing menthol are advertised and marketed as menthol cigarettes. If U.S government imposes the same treatment between flavored cigarettes (such as clove cigarettes) and menthol cigarettes in the form of bans circulating in the domestic market, this also means U.S government delivers domestic cigarette companies to go bankrupt severely.

The prohibition of flavored cigarettes in the U.S domestic market also brings significant advantageous for domestic tobacco companies, the Big Three in particular. U.S government has blatantly got rid of tobacco products competitors from domestic market competition. FSPTCA, if we delve into this, 
182 Puguh Toko Arisanto Trade Controversy Amidst Tobacco Control Provisions: Dynamics On The Establishment Of U.S Tobacco Control Act 2009

with two controversies strengthens the position of menthol cigarettes in the U.S domestic market instead. The involvement of tobacco companies in decision-making at TPSAC became another privileged concession from the U.S government.

From the discussions above, it can be argued that U.S government seems to carry out the view "harmony of interest" in need of stakeholder's involvement not only from the health sectors but also from the tobacco industries. Another view poses that tobacco industry's involvement in TPSAC can provide a balance input and enable them to work with stakeholders from health sector. In this case, U.S government provides a small portion of the economic considerations of tobacco companies in tobacco control act. It is important that tobacco control act doubtlessly in small or big scale faze tobacco industry's interests. It accordingly leads U.S government to harmonize between the interests of health sector and economic interests of U.S tobacco industries.

That FSPTCA is a win-win solution for cigarette companies and the civil society groups is the support emanating from those actors after FSPTCA had been issued in 2009. Although not all parties accepted all the provisions in FSPTCA but in general many of them provide implementation support. From civil society groups, supports come from Campaign for Tobacco-Free Kids, American Cancer Society Action Network, American Heart Association, etc. The FSPTCA was also claimed to grab the support of more than one thousand organizations of public health and religion. A survey showed that $70 \%$ voters supported FSPTCA after passing Congress. ${ }^{44}$ Aside from civil society groups, the tobacco industries such as Philip Morris (along with Altria Group) as the largest tobacco company

\footnotetext{
44 'FDA Regulation of Tobacco Products: A Common Sense Law to Protect Kids and Save Lives,' Campaign for Tobacco Free Kids, https://www.tobaccofreekids.org/research/factsheets /pdf/0352.pdf, Accessed 28 September 2016.
}

in the U.S on its website expressed its support for FSPTCA. $^{45}$ Philip Morris became the strongest supporter among other tobacco companies. Reynolds, Lorillard and the others partially supported the provisions of policy especially regarding illicit trade provisions and cigarette prevention arrangements for children. Yet, they also filed a lawsuit about the provisions of FSPTCA such as modified risk arrangements and cigarette packaging regulations that shut down free speech in advertising. ${ }^{46}$

\section{Conclusion}

The establishment of FSPTCA as a controversial tobacco control policy was inseparable from the roles of domestic interest groups namely tobacco companies and civil society groups whose their interest are opposing each other. They employed various means to influence or even pressure U.S government to issue favorable policy for their interests. In short, tobacco companies with their economics and political contributions influence U.S government not to ratify WHO FCTC. On the contrary, civil society groups had urged U.S government to ratify WHO FCTC for the sake of public health. Under this circumstance, U.S government inevitably sought to meet their contradicting interests as win-win solution. Lately, U.S government issued FSPTCA which adopted some important

\footnotetext{
45 'Altria Group and Its Tobacco Operating Companies Actively Supported Legislation that Gave the Food and Drug Administration (FDA) Authority to Regulate Tobacco Products,' Altria Group, http://www.altria.com/AboutAltria/Government-Affairs/programspractices/Legislative-Issues/Pages/FederalRegulation-of-Tobacco.aspx, Accessed 2 September 2016.

46 'District Court Denies Preliminary Injunction in a Case Challenging the Family Smoking Prevention and Tobacco Control Act,' Food and Drug Administration, http://www.fdalawblog.net/fda_law_blog_hyman_p helps/2009/11/district-court-denies-preliminaryinjunction-in-a-case-challenging-the-familysmoking-prevention-and.html, Accessed 27 September 2016.
} 
183 Puguh Toko Arisanto Trade Controversy Amidst Tobacco Control Provisions: Dynamics On The Establishment Of U.S Tobacco Control Act 2009

provisions of WHO FCTCT and accomodated interests of tobacco companies and civil society groups as win-win solution. After issued, FSPTCA derived support fully from many civil society groups while few tobacco companies supported fully and some supported partially.

\section{References:}

\section{Journal and Thesis:}

Collin, J. 'Tobacco Politics,' Palgrave Development, vol.47, issue 2, 2004, p.96.

Givel, M.S. \& Glantz, S.A. 'Tobacco Lobby Political Influence on US State Legislatures in the 1990s,' British Medical Journal, vol.10, Issue 2, no.124, 2001. p.3.

Liang, B.A., Pierce, J.P. Huber L. \&

Bostic, C. 'Call to Action: Promoting Domestic and Global Tobacco Control by Ratifying the Framework Convention on Tobacco Control in the United States,' PLOS Medicine, vol.11, issue.5, 2014, p.1.

Kartika, M.Y. 'Proteksionisme Amerika Serikat Pasca Krisis Finansial 2008,' Jurnal Analisis Hubungan Internasional UNAIR, vol.2 no.3, 2013, p.10.

Sherrick, J.E.M. Food, Drugs, and Cigarettes: The Influence of Politics on FDARegulations, University of Georgia, Atlanta, 2012, p.49-57.

Putnam, R.D.'Diplomacy and Domestic Politics: The Logic of Two-Level Game,' International Organization MIT, vol. 42, Issue. 3, 1988, p.436.

\section{Online Articles:}

'2009-2010: Inaugural Year in Review,' Food and Drug Administration Center for Tobacco Products, 2010, p.3, http://www.fda.gov/downloads/TobaccoProduc ts/NewsEvents/UCM216374.pdf, Accessed 25 August 2016.
'About the FSPTCA,' National Institute of Health, 2010, https://prevention.nih.gov/tobacco-regulatoryscience-program/about-the-FSPTCA, Accessed 1 August 2016.

'Altria Group and Its Tobacco Operating Companies Actively Supported Legislation that Gave the Food and Drug Administration (FDA) Authority to Regulate Tobacco Products,' Altria Group, http://www.altria.com/About-

Altria/Government-Affairs/programspractices/Legislative-Issues/Pages/FederalRegulation-of-Tobacco.aspx, Accessed 2 September 2016.

'American Cancer Society Cancer Action Network Launches Push for Ratification of Landmark Global Public Health Treaty,' American Cancer Society, 12 July 2006,

http://www.acscan.org/mediacenter/view/id/61 /, Accessed 20 September 2016.

'Candy and Fruit Flavored Cigarettes Now Illegal in United States; Step is First Under New Tobacco Law,' Food and Drug Administration, 2009, http://www.fda.gov/NewsEvents/Newsroom/Pr essAnnouncements/ucm183211.htm, Accessed 9 August 2016.

'China, World's Largest Cigarette Market, Ratifies Tobacco Treaty; U.S. Still On the Sidelines Because of Failure to Ratify', Campaign for Tobacco-Free Kids, 29 August 2005, http://www.tobaccofreekids.org/press_releases/ post/id_0866, Accessed 20 September 2016.

'District Court Denies Preliminary Injunction in a Case Challenging the Family Smoking Prevention and Tobacco Control Act,' Food and Drug Administration, http://www.fdalawblog.net/fda_law_blog_hym an_phelps/2009/11/district-court-deniespreliminary-injunction-in-a-case-challengingthe-family-smoking-prevention-and.html, Accessed 27 September 2016. 
184 Puguh Toko Arisanto Trade Controversy Amidst Tobacco Control Provisions: Dynamics On The Establishment Of U.S Tobacco Control Act 2009

'Family Smoking Prevention and Tobacco Control and Federal Retirement Reform,'U.S Government Publishing Office, 2009, https://www.gpo.gov/fdsys/pkg/PLAW111publ31/pdf/PLAW-111publ31.pdf, Accessed 9 August 2016.

'FDA Regulation of Tobacco Products: A Common Sense Law to Protect Kids and Save Lives,' Campaign for Tobacco Free Kids, https://www.tobaccofreekids.org/research/facts heets/pdf/0352.pdf, Accessed 28 September 2016.

'Follow-Up Implementation of Resolutions and Report Recommendations: AMA House of Delegates Annual Meeting June 14-19, 2003,' American Medical Association, 2003, http://www.amaassn.org/meetings/public/interim05/i04status.d oc, Accessed 21 September 2016.

'Guidelines for implementation of Article 5.3 of the WHO Framework Convention on Tobacco Control,' World Health Organization, http://www.who.int/fctc/guidelines/article_5_3. pdf, Accessed 13 August 2016.

$U C S F$,

'How to get Involved,' Rx for Change http://documentslide.com/documents/how-toget-involved.html, Accessed 2 September 2016.

'Interest Groups: Organizing to
Influence,
https://www.learner.org/courses/democracyina merica/dia_14/dia_14_topic.html, Accessed 22 September 2016.

Menthol Cigarettes,'Smokefree.gov, http://teen.smokefree.gov/Mentholcigarettes.aspx, Accessed 10 August 2016.

Smoking-Attributable Mortality, Years of Potential Life Lost, and Productivity Losses, United States, 2000--2004,' Centers for Disease Control and Prevention, November 2008, http://www.cdc.gov/mmwr/preview/mmwrhtm 1/mm5745a3.htm, Accessed 10 August 2016.

'State and Local Tobacco Tax Revenue, Selected Years 1977-2013,' Tax Policy Center, 2016, http://www.taxpolicycenter.org/statistics/tobac co-tax-revenue, Accessed 10 September 2016.

'The Global Tobacco Crisis: TobaccoGlobal Agent of Death,' World Health Organization, 2008, p.19, http://www.who.int/tobacco/mpower/mpower_ report_tobacco_crisis_2008.pdf?ua=1, Accessed 10 August 2016.

'The U.S. Commitment to Global Health: Recommendations for the Public and Private Sectors,' The National Academies, 2009, p.1-2.

http://sites.nationalacademies.org/cs/groups/int ernationalsite/documents/webpage/internationa 1_053818pdf, Accessed 2 September 2016.

'Tobacco, Money to Congress (Incumbent Only) 2000, 2002, 2004, 2006, \& 2008,' Center for Responsive Politics, https://www.opensecrets.org/industries/summa ry.php?cycle=2004\&ind=A02, [Accessed 16 September 2016].

'Tobacco: Long-Term Contribution Trends (2000, 2002, 2004, 2006, 2008), Center for Responsive Politics, https://www.opensecrets.org/industries/totals.p hp? cycle $=2016 \&$ ind $=A 02$, Accessed 17 September 2016.

'Tobacco: Top Contributors to Federal Candidates, Parties, and Outside Groups (2000, 2002, 2004, 2006, 2008),' Center for

Responsive Politics, https://www.opensecrets.org/industries/contrib. php?ind $=A 02 \& B k d n=$ DemRep $\&$ cycle $=2004$, Accessed 17 September 2016.

'Tobacco Industry,' Encyclopedia, November 2006 http://www.encyclopedia.com/history/unitedstates-and-canada/us-history/tobacco-industry, Accessed 12 September 2016. 
185 Puguh Toko Arisanto Trade Controversy Amidst Tobacco Control Provisions: Dynamics On The Establishment Of U.S Tobacco Control Act 2009

'Tobacco Products Scientific

Advisory Committee,' Food and Drug

Administration,

http://www.fda.gov/AdvisoryCommittees/Com mitteesMeetingMaterials/TobaccoProductsScie ntificAdvisoryCommittee/default.htm, Accessed 11 August 2016.

'Tobacco Tax Revenue and Forecast in the United States from 2000 to 2021* (in billion U.S. dollars),' The Statistics Portal, 2016, https://www.statista.com/statistics/248964/reve nues-from-tobacco-tax-and-forecast-in-the-us/, Accessed 7 September 2016.

'Top Export-Cigarettes 2003, 2004, 2005, 2006 \& 2007,' Food and Agricultural Organization, http://faostat.fao.org/site/342/default.aspx, Accessed 17 September 2016.

'Updated Status of the WHO FCTC: Ratification and Accession by Country,' Framework Convention Alliance, 2009, p.9, http://www.fctc.org/publications/other-fcapublications/doc_view/131-updated-status-ofthe-who-fctc-ratification-and-accession-bycountry, Accessed 20 August 2016.

David, 'A Review of the Global Tobacco Industry,' Topforeignstocks, 14 November 2010, http://topforeignstocks.com/2010/11/14/areview-of-the-global-tobacco-industry/, Accessed 2 September 2016.

Glantz, S. Mamudu, H.M. \& Hammond, R. 'Tobacco Industry attempts to counter the World Bank Report Curbing the Epidemic and Obstruct the WHO Framework Convention on Tobacco Control,' National Center for Biotechnology Information, 2008, https://www.ncbi.nlm.nih.gov/pmc/articles/PM C2662513/, Accessed 17 September 2016.

\author{
Miller,L. 'Interest Groups,' Collin \\ College, \\ https://iws.collin.edu/lmiller/2305\%20Powerpo \\ int/13\%20Interest\%20Groups.pptx, Accessed
}

20 September 2016.

Nedzhvetskaya, N. \& Powell, J.A.

'Who Do You Support,' The harvard Crimson, 2011, http://www.thecrimson.com/article/2011/4/11/t obacco-use-states-you/, Accessed 20

September 2016.

Nichter et al, M. 'The WHO Framework Convention on Tobacco Control, An Urgent Call for U.S. Ratification Alcohol, Drug, and Tobacco Study Group (ADTSG),' Medical Anthopology Quarterly, 2007, http://www.medanthro.net/policy/priorstatements/tobacco-control/, Accessed 2 September 2016.

Siegel, 'TPSAC Menthol Report Answers The Scientific Questions, But Doesn't Tip Committee's Hand, Demonstrating This Is About Policy And Politics, Not Science,' Tobacco Analysis, 18 March 2011, http://tobaccoanalysis.blogspot.co.id/2011/03/t psac-menthol-report-answers-scientific.html, Accessed 16 August 2016.

Simms, J. 'The Political Economy of the Tobacco Industry,' Elon University, http://org.elon.edu/ipe/simms.pdf, Accessed 2 June 2016.

Simpson, M. 'US Politics: Pressure Groups, Newtown and the NRA,' Tutor $2 u$, http://www.tutor2u.net/politics/blog/revisionupdate-us-politics-pressure-groups-newtownand-the-nra, Accessed 2 September 2016.

Online interview with Chris Bostic, Deputy Director for Policy of FCA, 10 August 2016. 